DOI https://doi.org/10.30525/978-9934-26-004-9-34

\title{
ТРИПІЛЬСЬКІ ДЖЕРЕЛА УКРАЇНСЬКОЇ КУЛЬТУРИ
}

\author{
Ульянова В. С. \\ доктор педагогічних наук, дочент, \\ дочент кафедри музично-інструментальної підготовки вчителя \\ Комунального закладу «Харківська гуманітарно-педагогічна академія» \\ Харківської обласної ради \\ м. Харків, Україна
}

Шість тисяч років тому на землі, яку сьогодні називають Україною, стояли величезні поселення - міста. Коли «історія починалася в Шумері», руїни вже давно були сховані під різнотрав'ям степу між Бугом i Дніпром. Люди, яких ми називаємо трипільцями, заклали підвалини цивілізації на нашій землі. Вони одними з перших тут почали вирощувати хліб і плавити метал, збудували тисячі селищ, десятки міст. Вони прагнули вічного життя, молячись і приносячи пожертви Вищим Силам, створили дивовижні магічні орнаменти, які зачаровують нас i сьогодні.

Про трипільську культуру впродовж останніх років ведеться багато дискусій у наукових колах, поміж політиків, ідеологів. Суперечки в середовищі ії шанувальників. У 2003 році товариство «Просвіта» провела кілька наукових конференцій із метою глибше осягнути таємниці цієї видатної цивілізації, що бентежить уяву прискіпливих дошукувальників правдивої історичної давнини нашої Вітчизни [5].

Уже понад століття багато вчених, намагаються переконати людство, як постала ця унікальна археологічна культура, що проіснувала 2700 років винятковою етнокультурною цілістю й, безсумнівно, вплинула на формування та духовний розвиток європейських народів.

Трипільська культура не залишила після себе ні пірамід, ні величних храмів, ні кам'яних палаців, а іiі матеріальна спадщина, всі свідчення існування понад шість тисячоліть заховані в землі. Археологи вирізнили 17 типів посуду різного призначення: кухонний, господарський, ритуальний і виявили в житлах близько 300 посудин для побутових потреб. Умільці володіли секретами високоякісного випалювання посуду у двоярусних горнах. Існували гончарні центри. Відомі спеціальні майстерні у трипільських селищах Уланівка, Шкарівка, Веселий Кут (Черкащина), Кліщів, Тростянець (Поділля) [4]. 
За підрахунками вчених, мінімальна кількість жителів, які відносилися до трипільської культури, нараховувала не менше одного мільйона. Археологи та палеоантропологи встановили, що носії трипільської культури належали до середземноморської раси, поширеної у ПівденноСхідній Європі. Це були невисокі люди з гарно профільованими рисами обличчя. Трипільське суспільство було конфедерацією племінних союзів, а гігантські на той час міста - їхніми столицями. В основі суспільного устрою трипільців лежали матріархальні племена, а згодом - i патріархальні родові відносини. Основною ланкою трипільського суспільства була сім'я. Сім'ї об'єднувалися в роди, кілька родів становило плем'я, група племен утворювала міжплемінні об'єднання, що мали свої етнографічні особливості. Найбільш високого культурного рівня розвитку досягли трипільські племена, котрі жили на Покутті, Наддністрянщині, Буковині. Якою ж є роль трипільської протоцивілізації в походженні української нації? Зокрема, дослідник П. Штепа у своїй праці «Московство», досліджуючи походження українського народу, також говорив, що «...5 тисяч років тому в Праукраїні існувала якась величезна від Волги до Дунай держава. Проте в цій державі було перенаселення. Тоді в Європі жило багато людей, серед них було багато нащадків тих українців, які переселились туди за попередні століття. Відтак трипільці заселили значну частину Східної Європи, Подунав'я, Балкани, Грецію. Історичні джерела вказують, що трипільці далі Волги не йшли. До далеких країв переселялися лише ті племена, чиїм заняттям було скотарство» [2, с. 16]. Трипілля, як висока цивілізація, як і всі високі цивілізації, припинила своє існування тоді, коли це стало завгодно Історії. Але якщо придивитися до виробів місцевих племен наступних поколінь - культур бронзового століття: «ямників», «катакомбників», «зрубників», ми помітимо, що на їхньому посуді присутні трипільські символи. Вони чітко виявляються й у кераміці залізного віку (скіфо-грецького періоду), на сірих вазах Черняхівської культури. Той же орнамент, ті ж сільськогосподарські технології, такі ж самі обряди. Навіть зараз в Україні можна зустріти обмащені глиною, яскраво розфарбовані «трипільські» мазанки, а символіка українських візерунків на рушниках і сорочках має прототипи у трипільських керамічних розписах - 180 поколінь між українцями й трипільцями пов'язані тисячами ниточок традицій, спільних цінностей, вірувань i тисячами авутинок ментальності. Невелика кількість достовірних свідчень про життя трипільців пояснюється браком матеріальних надбань тієї доби $[1$, с. 96].

У вчених багато запитань до життєвого устрою трипільської культури. Проіснувавши близько 2 тисяч років, трипільська культура зникла, асимілювалася з іншими культурами, які у різні періоди історії займали панівне становище на українських землях. Причиною занепаду 
цивілізації була економічна криза. Трипільці не знали озимих, і літній неврожай призводив до голоду. Спочатку їх виручало мисливство, але невдовзі всі природні ресурси було вичерпано: диких тварин відстріляли, коріння з'їли, навіть слимаків і черепах не залишилося (запечена черепаха, до речі, вважалася великим делікатесом). Гнані голодом люди покидали нажиті місця. Численні людські фігурки свідчать, що у Трипільців був поширений культ жінки. Трипільці також шанували свійських тварин. За глинними фігурками вдалося встановити, що тканини, які виготовляли стародавні жителі України, мали візерунки, а це вимагає від виробників знання досконалих технологій ткацтва. Та й кравці 3 них були вдалі, - самих лише жилеток придумали близько 123 моделей, а жінки прикрашали себе більш десяти видами зачісок, серед яких були знані нам косички та вузли. Цінність вивчення Трипільської культури не підлягає сумніву [3, с. 102].

Науковці з усього світу вважають пам'ятки культури Кукутені Трипілля (а саме так вона «офіційно» називається) свідченнями розбудови першої міської цивілізації. 3 метою збереження місцевості від глибокої оранки та грабежів 13 березня 2002 року прийнята постанова уряду про утворення державного історико-культурного заповідника «Трипільська культура» у Черкаській області. До нього увійшла територія 11 поселень трипільської культури: Тальянки(450га), Майданецьке (200га), Веселий Кут (150га), Онопрієва, Глибочок, Піщана (Тальнівського району), Доброводи, Косенівка, Аполянка (Уманського), Чичеркозівка, Вільховець (180га), (Звенигородського районів). Феномен зникнення трипільської культури ще i сьогодні залишається нерозгаданим. $\mathcal{C}$ припущення, що трипільська культура поступово підударами кочівників трансформувалася.

\section{Література:}

1. Баханов К.О. Професійний довідник вчителя історії . Х.: Основа, 2011. C. 88-166.

2. Бурдо Н.Б. Населення раннього етапу Трипільської культури межиріччя Дністра та Південного Бугу. К., 1993. С. 16-19

3. Давня історія України. Книга 1. - Київ: Либідь, 1994. 240 с.

4. Журнал виртуальных путешествий «Вокруг света» http://www.vokrugsveta.com/index.php?option=com_content\&task=view\&id $=557 \&$ Itemid $=71$

5. Олександр Стражний. Авторська літературна сторінка. Український менталітет. http://www.astra-lit.com/ukr-ment-ukr/ 03_tripilla.htm. 
6. Пометун О. Енциклопедія інтерактивного навчання. Бібліотека журналу Історія і суспільствознавство в школах України: теорія та методика навчання. 2014. № 5-6(8). 95 с.

DOI https://doi.org/10.30525/978-9934-26-004-9-35

\title{
СТАНОВЛЕННЯ ДИТЯЧОГО ХОРОВОГО ПРОФЕСІОНАЛІЗМУ В УКРАЇНІ У ДЗЕРКАЛІ ТВОРЧОЇ ПОСТАТІ ЕЛЕОНОРИ ВИНОГРАДОВОЇ
}

\author{
Щербій C. $O$. \\ аспірант \\ Навчально-наукового інституту мистецтв \\ ДВНЗ «Прикарпатський національний університет \\ імені Василя Стефаника» \\ м. Івано-Франківськ, Украӥна
}

Історія особистостей, які своєю творчістю й життям утверджують одвічно духовні цінності, творить українську хорову культуру. В плані концепції потенціалу в соціальній та індивідуальній життедіяльності показовою $є$ постать української диригентки, педагога і громадського діяча Е. Виноградової, для якої мистецька діяльність була невід'ємною частиною життєвого процесу.

Творча постать Елеонори Олексіївни (1931 - 2003) вирізняється мистецькою неповторністю і високою духовністю. Митець і педагог, заслужений діяч мистецтв України, професор Національної музичної академії України ім. П. Чайковського Елеонора Виноградова своїм творчим життям сприяла розвитку українського дитячого хорового співу, класичні традиції якого вона плекала понад три десятиліття. На всіх етапах довгої мистецької дороги вона послідовно і цілеспрямовано відстоювала високий професіоналізм і відданість своєму покликанню. Важливою умовою успішної творчості було сприйняття нових ідей, здатність знаходити і порушувати проблеми, критичність і сміливість, завзятість та наполегливість. Ї̈і творче мислення постійно стимулювало процес - створення чогось нового на різних етапах (постановка нової проблеми, відшукання нових способів іiї розв'язання, отримання нового результату) [2]. 